\title{
Consumer Acceptance of Functional Foods in Ho Chi Minh City
}

\author{
Duy Tung BUI*
}

\begin{abstract}
The aim of this paper is to identify and evaluate the underlying factors affecting consumer acceptance of functional foods. The contribution of this study is to better understand customer willingness to buy such products in Ho Chi Minh City by shedding light on how socio-demographic, cognitive and attitudinal determinants affect consumer's choices of foods. We conducted a survey using 217 respondents from Ho Chi Minh City. Next, we develop a binary-probit model to quantify the impact of each factor on consumer acceptance. The results show that having a sick relative, beliefs in health benefits positively affect acceptance level. Other than that, old people in Ho Chi Minh City tend to reject the use of functional foods. However, when they are provided with enough knowledge, they are the most intensive buyers of these products. Implications and further researches are also discussed.
\end{abstract}

Keywords: Functional food, Consumers acceptance, Binary-probit, Knowledge, Health.

JEL Classification: M31, D12

UDC : 339.133.017(510)

*University of Economics Ho Chi Minh City, Vietnam, E-mail: tungbd@ueh.edu.vn. 


\section{Introduction}

In Nielsen's (2013) report, Vietnamese consumers concern much about their health, right after their worries about an unstable macroeconomic context, unemployment and inflation. However, in their 2014's report, Nielsen stated that the first and foremost concern of Vietnamese consumers had been altered to healthcare. In 1995, healthcare expenditure per capita in Vietnam was only 20 USD and among the lowest in the South East Asia. However, this figure reached 80 USD in 2009, which equaled the healthcare expenditure per capita of Indonesian and Philippine.

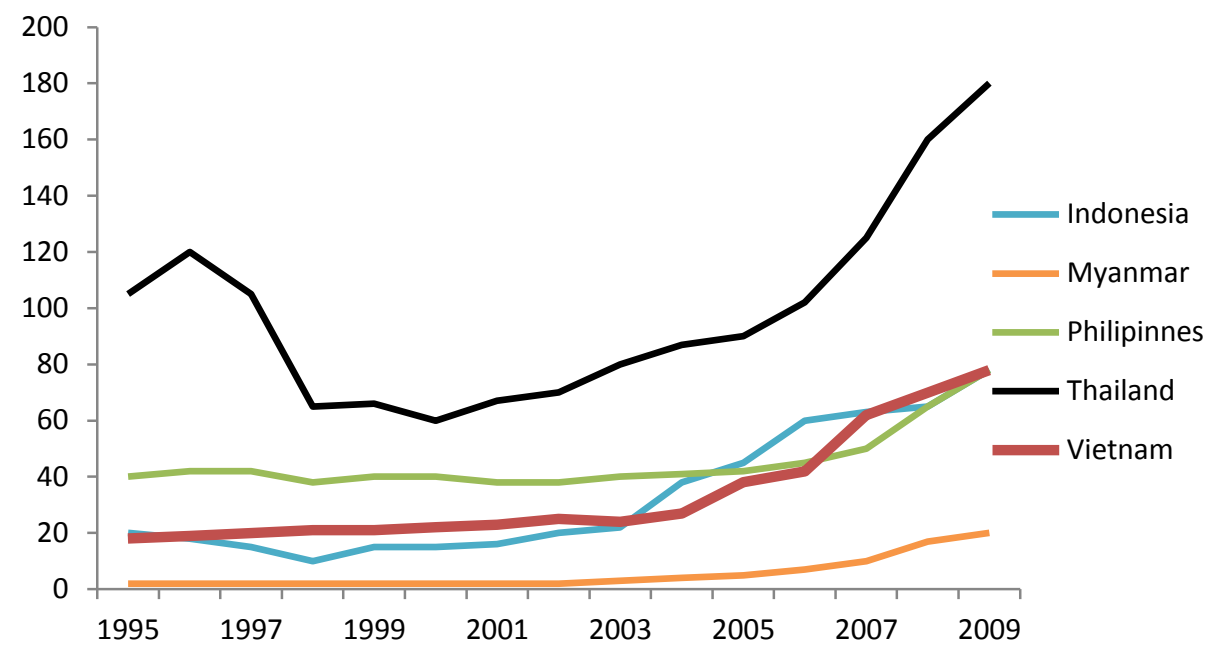

Figure 1: Healthcare expenditure per capita in some Asian economies (USD/year)

Not only Vietnamese people but also consumers worldwide consider healthy eating a good way to improve their physical condition (Nielsen, 2014; Bigliardi \& Galati, 2013; Mollet \&Rowland, 2002; Young, 2000). People tend to use many types of food in their daily meals to fulfil their nutrition needs. People who care about their health are more likely to use functional foods (Goetzke et al., 2014). Furthermore, Dang (2013) reported that Vietnam's functional food market has witnessed the birth of approximately 10,000 types of functional foods produced by more than 3,500 companies from 2011 to 2013 . The growing demand of functional foods is in connection with the increasing cost of healthcare and the demand of longer life expectancy (Siegrist et al., 2015; Siro et al., 2008; Kotilainen et al., 2006).

The astounding emergence of new companies fortifies the potential development of the functional food sector. There is a worldwide phenomenon that considerable 
resources in food industry and academic researches were allocated in finding new types of functional foods and new technologies (Khan et al, 2013; Betoret et al., 2011). It has been showed in the literature that consumer acceptance of the concept of functional foods and a thorough awareness of its determinants is crucial for market orientation and development. Despite that, comprehensive study has not yet been conducted to understand the consumer's perceptions and acceptance of functional foods in Vietnam, especially in Ho Chi Minh City. To shed some light on the issue, we conduct an empirical analysis to determine important factors affecting consumers' view and acceptance of functional foods in Ho Chi Minh City.

\section{Literature review}

Functional foods were first appeared in Japan in 1991 in the name of FOSHU, which meant "Foods for Specific Health Use". A FOSHU is a kind of ordinary food that has been proven beneficial for human's health.

Table 1: Type and example of functional foods (Shamal \& Mohan, 2015; Siro et al., 2008).

\begin{tabular}{l|l|l}
\hline $\begin{array}{l}\text { Type of } \\
\text { functional foods }\end{array}$ & Definition & Example \\
\hline $\begin{array}{l}\text { Fortified } \\
\text { products }\end{array}$ & A food with extra nutrients added & $\begin{array}{l}\text { Fruit juices fortified with } \\
\text { vitamin C, milk fortified with } \\
\text { vitamin D, calcium-fortified } \\
\text { orange juice, mineral } \\
\text { fortified breakfast cereals }\end{array}$ \\
\hline $\begin{array}{l}\text { Enriched } \\
\text { products }\end{array}$ & $\begin{array}{l}\text { A food added with nutrients in } \\
\text { order to replace vitamins or } \\
\text { minerals that have been lost during } \\
\text { the manufacturing process. }\end{array}$ & $\begin{array}{l}\text { Refining wheat to make } \\
\text { white flour removes several } \\
\text { B-complex vitamins and iron } \\
\text { that are contained in the } \\
\text { part of the grain that's } \\
\text { removed. }\end{array}$ \\
\hline Altered products & $\begin{array}{l}\text { A food from which a deleterious } \\
\text { component has been removed, } \\
\text { reduced or replaced with another } \\
\text { substance with beneficial effects }\end{array}$ & $\begin{array}{l}\text { Fibers as fat releasers in } \\
\text { meat or ice cream products }\end{array}$ \\
\hline $\begin{array}{l}\text { Enhanced } \\
\text { commodities }\end{array}$ & $\begin{array}{l}\text { A food in which one of the } \\
\text { components has been naturally } \\
\text { enhanced through special growing } \\
\text { conditions, new feed composition, } \\
\text { genetic manipulation, or otherwise }\end{array}$ & $\begin{array}{l}\text { Eggs with increased omega-3 } \\
\text { content achieved by altered } \\
\text { chicken feed }\end{array}$ \\
\hline
\end{tabular}

According to International Life Sciences Institute - ILSI (2002) "a food can be regarded as functional if it has been satisfactorily demonstrated to affect beneficially one or more target functions in the body beyond adequate nutritional 
effects in a way that is relevant to either an improved state of health and well-being and/or a reduction of risk of disease". Other than that, Diplock et al. (1999) point out that functional food "is not a pill or a capsule, but part of the normal food pattern". In this study, we use the above-mentioned definitions of functional foods. Functional foods take the form of ordinary foods but they are capable of promoting health and physiological status. There are four main types of functional foods including fortified products, enriched products, altered products, and enhanced commodities (Shamal \& Mohan, 2015; Siro et al., 2008).

Many empirical researches of consumer acceptance using primary data have been conducted in the US and Europe (Siegrist et al., 2015; Ding et al., 2015; Gilbert, 2000; IFIC, 1999, 2000; Wrick, 1995; Niva, 2000, 2007, Anttolainen et al., 2001; Bech- Larsen et al., 2001; Makela \& Niva, 2002; Urala \& Lahteenmaki, 2003, 2004, 2006, 2007; Verbeke, 2005, 2006; Verbeke et al., 2001; Van Kleef et al., 2005; Korzen-Bohr\&O'doherty Jensen, 2006; Devcich et al., 2007). These papers focused on different aspects, namely, food concept's awareness, consumers' attitude and acceptance, using various approaches including both qualitative and/or quantitative methods (Siro et al., 2008; Verbeke, 2005).

According to these studies, consumers in the US and European continent had inconsistent points of view regarding the acceptance of functional foods. In 1990s, American consumers accepted the concept of functional foods and tried to integrate them into their daily consumption. Nonetheless, the lasted results showed that there was a declining trend in the consumption in the US due to decreasing in taste and satisfaction (Siro et al., 2008). Consumers in Europe, however, were more critical in the choice of foods than their American counterpart despite the increasing importance of healthy foods in their daily intake (BechLarsen \& Grunert, 2003; Lusk et al., 2004; Lusk \& Rozan, 2005; Siro et al., 2008). European consumers viewed functional or modified foods as "unnatural an impure", especially Danish consumers (Siro et al., 2008). They feared the artificial process of functional foods' production and thus questioned about their safety (Poppe\&Kjærnes, 2003). In brief, previous studied showed that acceptance of functional foods depended not only on their health claims but also on their taste (Žeželj, 2012; Lalor, 2011; Lonneker, 2007; Patterson, 2006; Urala et al., 2003; Verbeke, 2005, 2006). Consumers often consider taste the first and foremost requirement in purchasing and consuming foods. If foods are less tasty, there will be high chance of rejection in spite of their nutrition and benefits to human. Even in the functional foods market, taste has been considered as "critical factors" affecting consumer behavior (Verbeke, 2005).

According to previous empirical studies, consumer acceptance can be affected by various determinants, including socio-demographic factors, cognitive and attitudinal factors (Shamal \& Mohan, 2015; Büyükkaragöz et al., 2014; Bornkessel et al., 2011; Jayasree, 2011; Siro et al., 2008; Verbeke, 2005; Bech-Larsen \& Grunert, 2003; Cox et al.,2004; Urala \& Lahteenmaki, 2004). 
Consumer knowledge and beliefs have been identified as the most important determinants of their acceptance (Del Giudice \& Pascucci, 2010; Verbeke, 2005). Furthermore, Fortin and Renton (2003) pointed out three factors governing customer attitude towards modified foods: the perceived attributes of the food product, the perceived consequences of buying and consuming the product and the attitude towards genetic engineering in food production in general. Therefore, consumer knowledge and awareness of the health benefits of the ingredients control their willingness to buy or use the product. In the literature, many researchers have tested the impact of functional ingredients such as fiber in bread, plant sterols in yoghurt and health benefit on the customers' willingness to consume the foods (Sandmann et al., 2015; Bitzios et al., 2011; Marette et al., 2010). The same results are found in Hilliam's research for the UK market. In an earlier study of IFIC, lack of knowledge can lead to rejection of functional foods in the US market (Siro et al., 2008).

Other than knowledge, beliefs were also recognized as major factors that influence the customers' acceptance. Beliefs have been conceptualized in various settings, as summarized in Table 2 . Those studies have unitedly shown that beliefs in the product positively affected the consumers' acceptance. In recent study of Devcich et al. (2007), "modern health worries" lead the consumers to the choice of functional food that protect them from technology-related disease.

\section{Table 2: Different concept of consumers' beliefs in functional foods Concept of consumers' beliefs in functional foods Source}

Belief in impact on personal heath

Belief in health benefit

Perceived role of food for health

(Hilliam,1996)

(Child, 1997; Verbeke, 2005)

(Sandmann et al., 2015; Bech-Larsen \& Grunert, 2003; Verbeke, 2005)

Belief in the protection from disease (Jain et al, 2014; Wrick, 1995)

Belief in the relationship between (Niva, 2000) eating and health

Shepherd (1999) has shown that even though attitudinal determinants could not entirely explain the consumers' willingness to buy, they were still by far the best predictor of behavior. Besides that, socio-demographic factors also play an important role in determining consumers' acceptance. Among those factors, age, education and sex emerge as key determinants. Verbeke (2005) also examined the impact of having children less than 12 years old and having sick family members on consumers' acceptance of functional foods.

Previous empirical studies have found that older people had more intention to purchase functional foods to address certain health issues (Verbeke, 2005; Poulsen, 1999; IFIC, 1999, 2000; Childs, 1997; Gilbert, 1997). Higher acceptance level has been found among 35 - 55 age group, 45 - 74 age group and mostly among 55+ 
age group since they were better aware of their personal health problems than younger people were. Likewise, higher education also leads to higher acceptance of functional foods, as educated people are more willing to pay a price premium. They are also believed to have better knowledge and awareness (Siro el al, 2008; Gilbert, 1997; Hilliam, 1996). Most studies have unanimously concluded that female buyers were more intensive than male buyers (Siro et al., 2008; Bech-Larsen \& Scholderer, 2007; Verbeke, 2005). Verbeke (2005) explained that women are mostly in charge of buying foods for the family and they tend to think more about health problems and eating healthily.

Apart from that, households with young children, e.g. children less than 12 years old, have more intention to search for foods that boost their children's health. They want to ensure the healthiest development of their children through nutritious meals (Siro et al., 2008; Maynard \& Franklin, 2003; Verbeke et al., 2000). Another socio-demographic determinant is the presence of sick family members. This experience renders the consumers to be more protective against such disease. They will thus use preventative eating methods to prevent the return of past disease (Verberke, 2005; Childs, 1997; Wrick, 1995)

\section{Methodology}

From the literature, we derived six hypotheses to identify which factors determine the consumers' acceptance of functional foods in Ho Chi Minh City. The sociodemographic determinants were hypothesized as:

H1: Being older does not affect the acceptance level.

H2: Female consumers' acceptance is higher than male counterpart.

H3: Having children does not affect the acceptance level.

H4: Having sick relatives does not affect the acceptance level.

For the cognitive and attitudinal determinants, we want to test two hypotheses:

H5: Beliefs in health benefit from functional foods does not affect the consumer acceptance.

H6: Knowledge of food benefits and food ingredient does not affect the consumer acceptance

A cross-sectional sample of 217 consumers was collected in Ho Chi Minh City. Respondents were identified by convenience sampling method. We collected their personal information including age, gender, children and sick family members. They were then provided with a definition of functional foods based on the work of Diplock et al. (1999). After that, they were going to answer multiple cognitive and attitudinal questions. In this sample, 17 cases were removed because the respondents had answered inconsistently or left some of the items unanswered. Thus, the final sample consists of 200 valid questionnaires. 
We used two Likert-scaled questions to examine the acceptance level of functional foods. Verbeke (2005) proposed a procedure to determine acceptance level, which control the problem of optimistic response bias; the trade-off on taste and inconsistent answers. In this method, inconsistencies happen when a respondent answer the question "I accept functional foods as long as they are tasty" with a score lower than 3 and the question "I accept functional foods despite the fact that they are less tasty than traditional foods" with a score higher than 2. We thus remove such observation $(n=12)$. We then constructed our dependent variable following Verbeke's procedure: the "rejection of functional foods based on taste is equaled to a decisive "no".

The independent variables consist of both continuous and discrete variables. We treat age, gender, sex, kid and sick relatives as dummy variables, whereas we transformed cognitive and attitudinal determinants into continuous variables based on the reliability Cronbach's alpha coefficients. We also use separate model, in which knowledge entered as continuous or discrete variable, to investigate the interactions between knowledge and other covariates. All the cognitive and attitudinal determinants have the coefficient alpha higher than 0.7 , which implies reliability and consistency, except for "Perceived role of food for health" (0.393). The last factor is thus removed from the final model.

\section{Table 3: Scale reliability scores.}

\begin{tabular}{lc}
\hline \multicolumn{1}{c}{ Factor } & Cronbach's Alpha \\
\hline Knowledge of functional foods & 0.787 \\
Beliefs in health benefits & 0.793 \\
Perceived role of food for health & 0.393 \\
\hline
\end{tabular}

We then applied binary-probit model to investigate the relationships between the variables. Since our dependent variable is a dummy variable whose value is 1 if the respondent accepts the functional food and 0 otherwise, using a latent variable approach is considered appropriated. The consumers' acceptance variable is labelled " $y$ " and thus, its latent value is " $y$ "”

$$
y_{i}^{*}=\beta_{0}+\sum_{k=1}^{K} \beta_{1} X_{k i}+u_{i}
$$

Where $y^{*}$ is an unobservable magnitude, which can be considered the net benefit to individual $\mathrm{i}$ of taking a particular course of action. This net benefit is not observable but the outcome of the individual can be observed by following the decision rule.

$$
\begin{aligned}
& y_{i}=0 \text { if } y_{i}^{*}<0 \\
& y_{i}=1 \text { if } y_{i}^{*} \geq 0
\end{aligned}
$$


That is, we observe that the individual did $(y=1)$ or did not $(y=0)$ accept the concept of functional food. The latent variable $y^{*}$ is thus related linearly to a set of factors $x$ and a disturbance process $u$. We have:

$$
\begin{gathered}
\operatorname{Pr}\left(y^{*}>0 \mid x\right)= \\
\operatorname{Pr}(u>-x \beta \mid x)= \\
\operatorname{Pr}(u<x \beta \mid x)= \\
\operatorname{Pr}(y=1 \mid x)=\psi\left(y^{*}\right)=\frac{e^{y *}}{\left(1+e^{y *}\right)^{2}}
\end{gathered}
$$

Where $\psi\left(y^{*}\right)$ is a cumulative distribution function of the normal distribution function.

\section{Results and analysis}

Our hypotheses about socio-demographic; cognitive and attitudinal determinants are tested using binary-probit model. Different from other empirical studies, which used bivariate analysis, we focus on multivariate analysis. We believed that the explanatory variables might interact with each other, thus yielding the results of correlation analysis inconsistent. Multivariate estimation results are reported in Table 4. We also report log likelihood value and percentage of correct predictions, which measure the goodness of fit of each model. Overall, our models present good power of prediction with the accuracy around $70 \%$.

Although the significance of the coefficients does not appear as expected, we are still able to extract interesting results from the estimation results. The sign of "Sex" coefficient is consistent with previous study, which means that women have more tendencies to accept the presence of functional foods in their daily diet. However, the coefficient is not significant. Same result can be concluded with the variable "Kid". Having children in the family would trigger parenting responsibilities; therefore, parents are likely to purchase additional foods to foster their children's development. However, the coefficient of "Kid" is not significant either. These results may be inconsistent with previous findings but Verbeke (2005) pointed out, most of the preceding researches examined the relationship through bivariate analysis. They do not account for the simultaneity of individuals' sociodemographic traits with knowledge and beliefs.

We also found evidence of a positive relationship between having a sick relative and acceptance of functional foods. The estimators show that impact of "Sick" on acceptance level is significant and robust. Consequently, we can safely reject $\mathrm{H} 4$ hypothesis, which states that having an ill family member does not affect the acceptance of functional foods. 
Beliefs in health benefit from functional ingredients are also the driving force of consumers' acceptance. Both sign and significant level of "Health benefit belief" appear as expected, rejecting $\mathrm{H} 5$ hypothesis.

Table 4: Estimation results

\begin{tabular}{|c|c|c|}
\hline & Model 1 & Model 2 \\
\hline \multirow[t]{2}{*}{ Sex } & 0.154 & 0.152 \\
\hline & $(0.81)$ & $(0.79)$ \\
\hline \multirow[t]{2}{*}{ Age } & $-1.465 * *$ & -0.0257 \\
\hline & $(-2.16)$ & $(-0.12)$ \\
\hline \multirow[t]{2}{*}{ Kid } & 0.0322 & 0.0244 \\
\hline & $(0.16)$ & $(0.12)$ \\
\hline \multirow[t]{2}{*}{ Sick } & $0.708^{* * *}$ & $0.632 * * *$ \\
\hline & $(3.36)$ & (3.09) \\
\hline \multirow[t]{2}{*}{ Health benefit beliefs } & $0.123 * * *$ & $0.129 * * *$ \\
\hline & $(3.07)$ & $(3.20)$ \\
\hline \multirow[t]{2}{*}{ Knowledge of functional foods } & $-0.398 *$ & \\
\hline & $(-1.76)$ & \\
\hline \multirow[t]{2}{*}{ Age(26 - 35)*Knowledge } & $0.646^{*}$ & \\
\hline & $(1.93)$ & \\
\hline \multirow[t]{2}{*}{ Age(35-50)*Knowledge } & $1.180^{*}$ & \\
\hline & $(1.67)$ & \\
\hline \multirow[t]{2}{*}{ Age $(50+) *$ Knowledge } & $4.918 * *$ & \\
\hline & $(2.36)$ & \\
\hline \multirow[t]{2}{*}{ Age*Medium knowledge } & & -0.212 \\
\hline & & $(-0.64)$ \\
\hline \multirow[t]{2}{*}{ Age*High knowledge } & & 0.683 \\
\hline & & $(1.21)$ \\
\hline \multirow[t]{2}{*}{ Medium knowledge } & & -0.134 \\
\hline & & $(-0.47)$ \\
\hline \multirow[t]{2}{*}{ High knowledge } & & $-0.721^{*}$ \\
\hline & & $(-1.69)$ \\
\hline \multirow[t]{2}{*}{ Constant } & 2.088 & $-1.478 *$ \\
\hline & $(1.22)$ & $(-1.78)$ \\
\hline Number of observations & 189 & 189 \\
\hline Pseudo R2 & 0.134 & 0.108 \\
\hline Log likelihood value & -112.3 & -115.6 \\
\hline Chi2 value & $34.67^{* * *}$ & $25.24 * * *$ \\
\hline Prediction power (\% of correct predictions) & $70.37 \%$ & $69.84 \%$ \\
\hline
\end{tabular}

Model 1 treats "Knowledge of functional foods" as continuous variable, whereas Model 2 considers it as categorical variable. $t$ statistics are reported in parentheses. ${ }^{* * *}, * *, *$ denote $1 \%, 5 \%$ and $10 \%$ level of significant respectively. ( ) reports t-statistic value of the coefficients. 


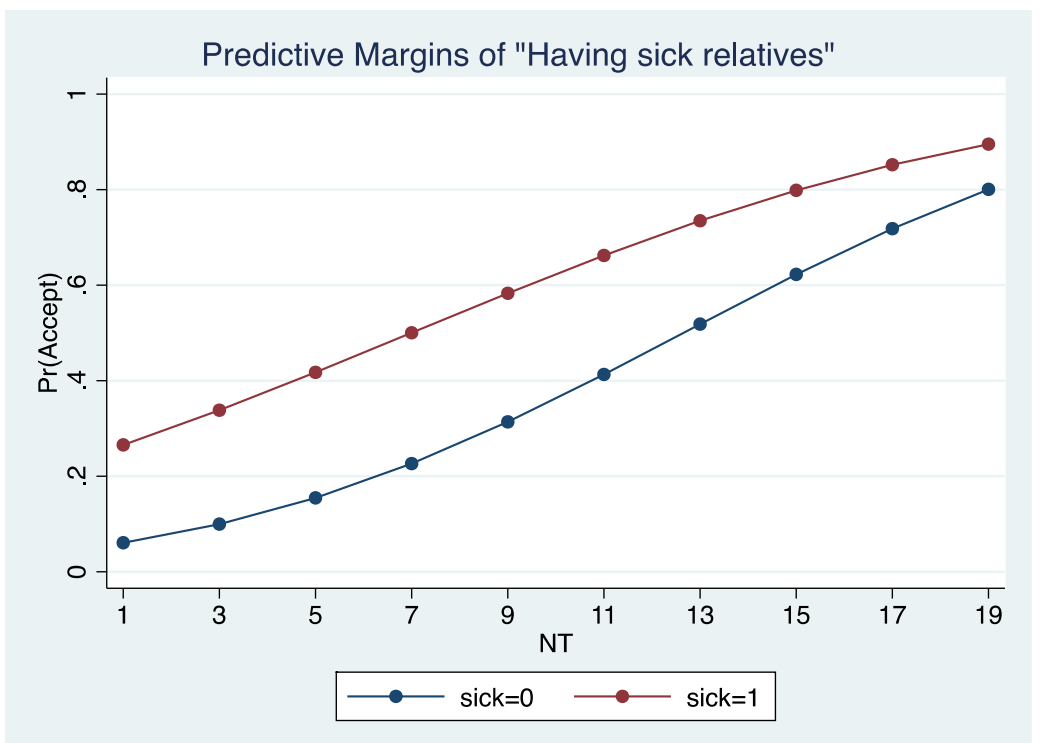

Figure 2. Predictive Margins of "Having Sick Relatives"

We treat "Knowledge" as both continuous and categorical variable and the results from the estimation table show that when being treated as continuous variable, "Knowledge" yields higher explanatory power. At first, the coefficient of "Age" in the first model has negative sign and conflicts with the literature. However, when "Age" is allowed to interact with "Knowledge", we were able to found interesting results. Interaction between the two variables brings positive and significant coefficients. This result implies variation of acceptance level across age groups. Elders in Ho Chi Minh City may lack of access to new technologies and development in the food market, especially functional foods. The traditional way of eating with conventional foods persists in their daily meals. Therefore, conservative elders may reluctant in accepting new definition of foods. Lack of knowledge makes them choose the less risky way of eating and thus, reject the concept of functional foods. However, when elders were accompanied with profound knowledge of the foods' health benefits and foods ingredients, they alter their behavior towards functional foods. Impact of high knowledge on functional food acceptance increases with age. This finding is in line with Verbeke (2005).

\section{Conclusions}

The main objective of the study is to identify and evaluate determinants of functional foods acceptance including socio-demographic determinants; cognitive and attitudinal determinants. Besides exploring the key factors affecting consumer acceptance of functional foods, this study contributes to the existing knowledge about consumer perception of functional foods and their willingness to purchase 
such products. The results also reinforce many conclusions in the previous researches.

In this study, we use cross-sectional data surveyed from 217 respondents in Ho Chi Minh City to examine the determinants of consumers' acceptance of functional foods. Multivariate-probit model was applied to investigate the relationships between socio-demographic factors; cognitive and attitudinal factors and the willingness of consumers to buy or consume functional ingredients.

The results reaffirm some of the hypotheses derived from the existing literature. First, health benefit beliefs still play an important role in determining consumers' acceptance. This conclusion is in line with recent studies (Kraus, 2015; Siegrist et al., 2015; Shamal \& Mohan, 2015; Ding et al., 2015; Jain et.al, 2014). Therefore, one of the most critical motivations behind the choices of functional foods relates to the improvement of consumer's health and the protection from disease. Consumer will be convinced to use functional foods if detailed information about the ingredients and health benefit is provided.

Moreover, the presence of a sick relative triggers the need to use more functional product to counter and prevent the return of the disease. Most interestingly, elders tend to refuse the consumption of functional foods. In the study of Van der Zanden el al. (2015), the elders are also doubtful about these products. This behavior can be explained by a lack of faith in functional foods (Landström et al., 2009; Poulsen, 1999) and by insufficient knowledge (Ares et al., 2008; Menrad, 2003; Wansink et al., 2005). On the other hand, the interaction between age and knowledge leads to the contrary conclusion. As we have seen, the likelihood to buy functional foods increase with age and knowledge. These results are consistent with (Verbeke, 2005) and confirm the findings of (Ares et al., 2008; Menrad, 2003; Wansink et al., 2005).

Other social-demographic factors including gender and having a kid in the family did not influence the functional foods choice. Many previous studies also confirm the failure of social-demographic factors in determining the choice of functional foods (Urala, 2005; Verbeke, 2005; Niva et al., 2003).

From these findings, manufacturer should pay more attention on communicating the components and health benefit to the consumers. As Van der Zanden et al. (2015) points out, the functional foods market has undergone lack of success relating to its failure to meet the consumer's expectation. Successfully conveying the information of the product's attributes to the potential customers would ensure the development of the market. Other than that, communicating campaigns aimed to increase the knowledge of the consumers, especially the elders would prevent the loss of a market segmentation.

The first limitation is the representative attribute of our sample. This sample is collected by convenient method so the results extracted from this study are the 


\section{Bui Duy TUNG}

best used for examining consumer acceptance determinants. Another limitation is that we should have evaluated consumer acceptance using actual consumption behavior rather than concept relating to taste. As a result, future studies should look in to the actual buying behavior to access the consumer acceptance variable. Other than that, we treated functional foods as one homogenous group while there are many types of foods. Therefore, further studies on specific types of functional foods should be considered.

To sum up, our research supports the process of decision-making of consumers through rationalization and acquiring knowledge and beliefs, which is consistent with the Theory of Planned Behavior. Furthermore, the most likely consumer could be depicted as "aged human with profound knowledge about health benefits of food and food ingredient, believes in health benefits and has a sick family member".

\section{References}

Anttolainen, M., Luoto, R., Uutela, A., D Boice, J. O. H. N., Blot, W. J., McLaughlin, J. K., \& Puska, P. (2001). Characteristics of users and nonusers of plant stanol ester margarine in Finland: an approach to study functional foods. Journal of the American Dietetic Association, 101(11), 1365-1368. http://dx.doi.org/10.1016/S0002-8223(01)00327-3

Ares, G., Giménez, A., \& Gámbaro, A. (2008). Influence of nutritional knowledge on perceived healthiness and willingness to try functional foods. Appetite, 51, 663-668. http://dx.doi.org/10.1016/j.appet.2008.05.061

Bech-Larsen, T., \& Grunert, K. G. (2003). The perceived healthiness of functional foods- A conjoint study of Danish, Finnish and American consumers' perception of functional foods. Appetite, 40, 9-14. http://dx.doi.org/10.1016/S0195-6663(02)00171-X

Bech-Larsen, T., Grunert, K. G., \& Poulsen, J. B. (2001). The acceptance of functional foods in Denmark, Finland and the United States. A study of consumers' conjoint evaluations of the qualities of functional food and perceptions of general health factors and cultural values. Working Paper No. 73. Aarhus, Denmark: MAPP.

Bech-Larsen,T., \& Scholderer J. (2007). Functional foods in Europe: consumer research, market experiences and regulatory aspects. Trends in Food Science \& Technology 18 (4), 231-234. http://dx.doi.org/10.1016/j.tifs.2006.12.006.

Betoret, E., Betoret, N., Vidal, D., \& Fito, P. (2011). Functional foods development. Trends and technologies. Trends in Food Science \& Technology, 22, 498-508. http://dx.doi.org/10.1016/j.tifs.2011.05.004

Bigliardi, B., \& Galati, F. (2013). Innovation trends in the food industry. The case of functional foods. Trends in Food Science \& Technology, 31(2), 118-129. http://dx.doi.org/10.1016/j.tifs.2013.03.006

Bitzios, M., Fraser, I., \& Haddock-Fraser, J. (2011). Functional ingredients and food choice: Results from a dual-mode study employing means-end-chain analysis and a choice experiment. Food Policy, 36(5), 715-725. http://dx.doi.org/10.1016/j.foodpol.2011.06.004

Bornkessel, S.; Bröring, S.; Omta, S.W.F, (2011), "Consumer Acceptance of Functional Foods and Their Ingredients: Positioning Options for Innovations at the Borderline between Foods and Drugs," International Food and Agribusiness Management Association 
Büyükkaragöz, Aylin, Bas, Murat, Sağlam, Duygu Cengiz and Şaziye Ecem, (2014), "Consumers' awareness, acceptance and attitudes towards functional foods in Turkey," International Journal of Consumer Studies, 38(6), 628-635. http://dx.doi.org/10.1111/ijcs.12134

Childs, N. M., \& Poryzees, G. H. (1997). Foods that help prevent disease: Consumer attitudes and public policy implications. Journal of Consumer Marketing, 14, 433-447. http://dx.doi.org/10.1108/07363769710186015

Cox, D. N., Koster, A., \& Russell, C. G. (2004). Predicting intentions to consume functional foods and supplements to offset memory loss using an adaptation of protection motivation theory. Appetite, 33, 55-64. http://dx.doi.org/10.1016/j.appet.2004.02.003

Dang, T. (2013). Vietnam's food market from 2000 to 2013. Vietnam Association of Functional Foods Report (VAFF)

Del Giudice, T., \& Pascucci, S. (2010). The role of consumer acceptance in the food innovation process: Young consumer perception of functional foods in Italy. International Journal on Food System Dynamics, 1(2), 111-122.

Devcich, D. A., Pedersen, I. K., \& Petrie, K. J. (2007). You eat what you are: Modern health worries and the acceptance of natural and synthetic additives in functional foods. Appetite, 48, 333-337. http://dx.doi.org/10.1016/j.appet.2006.09.014

Ding, Y., Veeman, M. M., \& Adamowicz, W. L. (2015). Functional food choices: Impacts of trust and health control beliefs on Canadian consumers' choices of canola oil. Food Policy, 52, 92-98. http://dx.doi.org/10.1016/j.foodpol.2014.12.002

Diplock, A. T., Aggett, P. J., Ashwell, M., Bornet, F., Fern, E. B., \& Roberfroid, M. B. (1999). Scientific concepts of functional foods in Europe: Concensus document. British Journal of Nutrition, 81(suppl. 1), S1-S27. http://dx.doi.org/10.1017/S0007114599000471

Fortin, D. R., \& Renton, M. S. (2003). Consumer acceptance of genetically modified foods in New Zealand. British Food Journal, 105(1/2), 42-58. http://dx.doi.org/10.1108/00070700310467483

Gilbert, L. (1997). Consumer market for functional foods. Journal of Nutraleuticals, Functional and Medical Foods, 1, 5-21.

Gilbert, L. (2000). The functional food trend: What's next and what Americans thinkabout eggs. Journal of the American College of Nutrition, 19, 507S-512S. http://dx.doi.org/10.1080/07315724.2000.10718973

Goetzke, B., Nitzko, S., \& Spiller, A. (2014). Consumption of organic and functional food. A matter of well-being and health?. Appetite, 77, 96-105. http://dx.doi.org/10.1016/j.appet.2014.02.012

Hilliam, M. (1996). Functional foods: The Western consumer viewpoint. Nutrition Reviews, (54): 189-S194. http://dx.doi.org/10.1111/j.1753-4887.1996.tb03846.x

IFIC. (1999). Functional foods: Attitudinal research (1996-1999). Washington, DC: International Food Information Council Foundation, IFIC.

IFIC. (2000). Functional foods. Attitudinal research. Washington, DC: International Food Information Council Foundation, IFIC.

ILSI Europe (2002) Concepts of functional foods. ILSI Europe Concise Monograph Series. Belgium. Jain, S., Sharma, K., \& Khadke, M. Consumer Behavior towards Functional Foods in India-A Study of Market Drivers \& Challenges. 


\section{Bui Duy TUNG}

Khan, R. S., Grigor, J., Winger, R., \& Win, A. (2013). Functional food product development. Opportunities and challenges for food manufacturers. Trends in Food Science \& Technology, 30(1), 27-37. http://dx.doi.org/10.1016/j.tifs.2012.11.004

Korzen-Bohr, S., \& O'doherty Jensen, K. (2006). Heart disease among post-menopausal women: Acceptability of functional foods as a preventive measure. Appetite, 46, 152-163. http://dx.doi.org/10.1016/j.appet.2005.11.003

Kotilainen, L., Rajalahti, R., Ragasa, C., \& Pehu, E. (2006). Health enhancing foods: Opportunities for strengthening the sector in developing countries. Agriculture and Rural Development Discussion Paper 30.

Kraus, A. (2015). Factors influencing the decisions to buy and consume functional food. British Food Journal, 117(6). http://dx.doi.org/10.1108/BFJ-08-2014-0301

Lalor, F., Madden, C., McKenzie, K., \& Wall, P. G. (2011). Health claims on foodstuffs: A focus group study of consumer attitudes. Journal of Functional Foods, 3(1), 56-59. http://dx.doi.org/10.1016/j.jff.2011.02.001

Landström, E., Koivisto, U., \& Magnusson, M. (2009). Functional foods compensate for an unhealthy lifestyle. Some Swedish consumers' impressions and perceived need of functional foods. Appetite, 53, 34-43. http://dx.doi.org/10.1016/j.appet.2009.04.219

Lonneker, J. (2007). Psychological impacts of health claims on consumer perception and behaviour. ILSI international symposium on functional foods in Europe.

Lusk, J. L., \& Rozan, A. (2005). Consumer acceptance of biotechnology and the role of second generation technologies in the USA and Europe. Trends in Biotechnology, 23, 386-387. http://dx.doi.org/10.1016/j.tibtech.2005.05.012

Lusk, J. L., House, L. O., Valli, C., Jaeger, S. R., Moore, M., Morrow, J. L., et al. (2004). Effect of information about benefits of biotechnology on consumer acceptance of geneti- cally modified food: Evidence from experimental auctions in the United States, England, and

France. European Review of Agricultural Economics, 31, 179-204. http://dx.doi.org/10.1093/erae/31.2.179

Makela, J., \& Niva, M. (2002). Changing views of healthy eating: Cultural acceptability of functional foods in Finland. Nordisk Sociologkongress, Iceland: Reykjavic.

Marette, S., Roosen, J., Blanchemanche, S., \& Feinblatt-Mélèze, E. (2010). Functional food, uncertainty and consumers' choices: A lab experiment with enriched yoghurts for lowering cholesterol. Food Policy, 35(5), 419-428. http://dx.doi.org/10.1016/j.foodpol.2010.04.009

Maynard, L. J., \& Franklin, S. T. (2003). Functional foods as a value-added strategy: The commercial potential of cancer-fighting dairy products. Review of Agricultural Economics, 25, 316-331. http://dx.doi.org/10.1111/1467-9353.00141

Menrad, K. (2003). Market and marketing of functional food in Europe. Journal of Food Engineering, 56, 181-188. http://dx.doi.org/10.1016/S0260-8774(02)00247-9

Mollet, B., \& Rowland, I. (2002). Functional foods: At the frontier between food and pharma. Current Opinion in Biotechnology, 13, 483-485. http://dx.doi.org/10.1016/S0958 1669(02)00375-0

Nielsen Vietnam (2013). Know Your Consumer - Grow Your Business. 2013 Pocket Reference Book: Vietnam.

Nielsen Vietnam (2014). Know - Act - Grow: Driving Smarter Business Decisions in Vietnam 2014. 2014 Pocket Reference Book: Vietnam 
Niva, M. (2000). Consumers, functional foods and everyday knowledge. Conference of nutritionists meet food scientists and technologists. Porto, Portugal.

Niva, M. (2007). 'All foods affect health': Understandings of functional foods and healthy eating among health-oriented Finns. Appetite, 48, 384-393. http://dx.doi.org/10.1016/j.appet.2006.10.006

Patterson, N. (2006). Exploring consumer attitudes. Taste versus convenience and healthWhat do consumers really want? In Proceedings of the third functional food net meeting.

Poppe, C., \& Kjærnes, U. (2003). Trust in food in Europe. A comparative analysis. Oslo: National Institute for Consumer Research. http://www.trustinfood.org/SEARCH/BASIS/tif0/all/publics/DDD/24.pdf.

Poulsen, J. B. (1999). Danish consumers' attitudes towards functional foods. Working. Paper No. 62. Aarhus, Denmark: MAPP.

Sandmann, A., Brown, J., Mau, G., Saur, M., Amling, M., \& Barvencik, F. (2015). Acceptance of vitamin D-fortified products in Germany-A representative consumer survey. Food Quality and Preference, 43, 53-62. http://dx.doi.org/10.1016/j.foodqual.2015.02.011

Shamal, S., \& Mohan, B. C. (2015). Functional Food Acceptance in India: Socio-Demographic and Lifestyle Determinants. 1st IIMA International Conference on Advances in Healthcare Management Services. Indian Institute of Management, Ahmedabad.

Siegrist, M., Shi, J., Giusto, A., \& Hartmann, C. (2015). Worlds apart: Consumer acceptance of functional foods and beverages in Germany and China. Appetite, 92, 87-93 http://dx.doi.org/10.1016/j.appet.2015.05.017

Siro, I., Kapolna, E., Kapolna, B., \& Lugasi, A. (2008). Functional food. Product development, marketing and consumer acceptance-A review. Appetite, 51(3), 456-467. http://dx.doi.org/10.1016/j.appet.2008.05.060

Urala, N. (2005). Functional foods in Finland. Consumers: Views, attitudes and willingness to use. Academic Dissertation. VTT Publication, 581.

Urala, N., \& Lahteenmaki, L. (2004). Attitudes behind consumer's willingness to use functional foods. Food Quality and Preference, 15, 793-803. http://dx.doi.org/10.1016/j.foodqual.2004.02.008

Urala, N., \& Lahteenmaki, L. (2006). Hedonic ratings and perceived healthiness in experimental functional food choices. Appetite, 47, 302-314. http://dx.doi.org/10.1016/j.appet.2006.04.007

Urala, N., \& Lahteenmaki, L. (2007). Consumers' changing attitudes towards functional foods. Food Quality and Preference, 18, 1-12. http://dx.doi.org/10.1016/j.foodqual.2005.06.007

Urala, N., Arvola, A., \& Lahteenmaki, L. (2003). Strength of health related claims and their perceived advantage. International Journal of Food Science and Technology, 38, 815-826. http://dx.doi.org/10.1046/j.1365-2621.2003.00737.x

Van der Zanden, L. D., van Kleef, E., de Wijk, R. A., \& van Trijp, H. C. (2015). Examining heterogeneity in elderly consumers' acceptance of carriers for protein-enriched food: A segmentation study. Food Quality and Preference, 42, 130-138. http://dx.doi.org/10.1016/j.foodqual.2015.01.016

Van Kleef, E., Van Trijp, H. C. M., \& Luning, P. (2005). Functional foods: Health claim food product compatibility and the impact of health claim framing on consumer valuation. 


\section{Bui Duy TUNG}

Appetite, 44, 299-308. http://dx.doi.org/10.1016/j.appet.2005.01.009

Verbeke, W. (2005). Consumer acceptance of functional foods: Sociodemographic, cognitive and attitudinal determinants. Food Quality and Preference, 16, 45-57. http://dx.doi.org/10.1016/j.foodqual.2004.01.001

Verbeke, W. (2006). Functional foods: Consumer willingness to compromise on taste for health? Food Quality and Preference, 17, 126-131. http://dx.doi.org/10.1016/j.foodqual.2005.03.003

Verbeke, W., Moriaux, S., \& Viaene, J. (2001). Consumer knowledge and attitude towards functional foods in Belgium: Evidence from empirical research. Annals of Nutrition and Metabolism, 45, 114.

Verbeke, W., Ward, R. W., \& Viaene, J. (2000). Probit analysis of fresh meat consumption in Belgium: Exploring BSE and television communication impact. Agribusiness, 16, 215-234. http://dx.doi.org/10.1002/(SICI)1520-6297(200021)16:2<215::AID-AGR6>3.0.CO;2-S

Wansink, B., Westgren, R. E., \& Cheney, M. M. (2005). Hierarchy of nutritional knowledge that relates to the consumption of a functional food. Nutrition (Burbank, Los Angeles County, Calif.), 21, 264-268. http://dx.doi.org/10.1016/j.nut.2004.06.022

Wrick, K. L. (1995). Consumer issues and expectations for functional foods. Critical Reviews in Food Science and Nutrition, 35, 167-173. http://dx.doi.org/10.1080/10408399509527696

Young, Y. (2000). Functional foods and the European consumer. In J. Buttriss \& M. Saltmarsh (Eds.), Functional foods. II. Claims and evidence. London, UK: The Royal Society of Chemistry. Žeželj, I., Milošević, J., Stojanović, Ž., \& Ognjanov, G. (2012). The motivational and informational basis of attitudes toward foods with health claims. Appetite, 59(3), 960-967. http://dx.doi.org/10.1016/j.appet.2012.09.008 